\title{
Pengaruh Brand Image (Citra Merek) terhadap Loyalitas Konsumen Produk Oli Pelumas Evalube di Kota Langsa
}

\author{
Erni Yunaida \\ Fakultas Ekonomi, Universitas Samudra \\ e-mail: erni_yunaida@gmail.com
}

\begin{abstract}
Abstrak
Penelitian ini bertujuan untuk mengetahui pengaruh brand image (Citra Merek) terhadap loyalitas konsumen produk oli pelumas evalube di kota Langsa. Adapun sampel yang digunakan berjumlah 96 orang. Metode analisis data yang digunakan adalah analisis regresi linier sederhana. Uji hipotesis yang dilakukan melalui uji parsial (uji t), dan uji koefisien determinasi $\left(R^{2}\right)$.Hasil uji $t$, brand image (citra merek) berpengaruh signifikan terhadap loyalitas konsumen produk oli pelumas evalube di kota Langsa Nilai koefisien determinasi $\left(R^{2}\right)$ diperoleh sebesar 0,375 atau 37,5\% yang artinya variabel brand image (citra merek) memberikan pengaruh terhadap loyalitas konsumen sebesar 37,5\% dan sisanya $62,5 \%$ dipengaruhi oleh variabel lain yang tidak diteliti dalam penelitian ini.
\end{abstract}

Kata Kunci: Brand Image dan Loyalitas Konsumen

\section{PENDAHULUAN}

Persaingan yang kompetitif menyebabkan perusahaan semakin sulit untukmeningkatkan jumlah konsumen. Banyaknya kompetitor dalam pasar dengan segala macam keunggulan produk yang ditawarkan membuat perusahaan semakin sulit merebut pangsa pasar. Hal ini menyebabkan perusahaan harus berkerja keras dalam meningkatkan pangsa pasar tersebut dengan menciptakan inovasi yang terbaru dan memaksimalkan sumber daya yang ada. Perusahaan tidak hanya sekedar menciptakan produk yang berkualitas, tetapi perusahaan juga harus berupaya agar produk yang dihasilkan dapat melekat di dalam benak konsumen.

Salah satu cara agar sebuah produk mudah dikenal dan diingat oleh konsumen adalah dengan membuat citra merek yang baik pada produk yang dihasilkan. Citra merek merupakan pembeda antara produk satu dengan produk lainnya dalam kategori produk tertentu. Citra merek menjadi fungsi strategis bagi perusahaan dalam menembus pasar yang semakin kompetitif. Suatu citra merek cenderung menciptakan sikap yang baik terhadap suatu produk dengan menjelaskan ciri-ciri positif sehingga dapat mempengaruhi perasaan dan emosional konsumen serta persepsi individu dalam memilih suatu produk.

Dalam melakukan pembelian suatu produk, sebagian konsumen biasanya mengutamakan merek untuk dijadikan pertimbangan dalam menetapkan pilihannya dari berbagai alternatif produk yang ada. Hal ini dikarenakan persepsi konsumen apabila menggunakan produk dengan citra merek yang baik membuat konsumen dapat meningkatkan rasa nyaman dan percaya terhadap suatu produk sehingga konsumen kembali menggunakan produk dengan merek yang sama.

Penggunaan suatu merek secara konsisten berdampak pada loyalitas konsumen. Loyalitas tercipta berdasarkan pengalaman konsumen dalam membeli dan menggunakan suatu produk, salah satunya adalah produk yang memiliki citra merek yang baik. Konsumen dapat dikatakan loyal apabila melakukan pembelian produk dengan merek yang sama secara berulang-ulang. Konsumen yang loyal tidak akan berpindah ke produk pesaing karena telah memiliki rasa emosional terhadap produk yang digunakan. Selain itu keterlibatan dan kepercayaan konsumen dalam upaya pencarian informasi 
produk juga menjadi faktor pembentuk loyalitas. Hal ini disebabkan oleh perkembangan arus informasi sehingga konsumen dapat menyerap informasi serta pengetahuan tentang suatu produk dengan cepat sehingga loyalitas konsumen terhadap suatu produk akan semakin meningkat.

Saat ini semakin banyak produk yang memiliki citra merek dan bersaing untuk mendapatkan pelanggan yang loyal. Salah satu produk yang memiliki citra merek yaitu produk oli pelumas Evalube. Dalam menghadapi produk pesaing yang semakin banyak beredar, produk oli pelumas Evalube berlomba mengeluarkan berbagai jenis inovasi dan mempertahankan kualitas produk guna mendapatkan konsumen yang loyal sehingga dapat merebut pangsa pasar yang tinggi. Produk oli pelumas Evalube telah dikenal sejak tahun 1997 sehingga produk tersebut telah memiliki citra merek yang baik dan konsumen yang setia sampai sekarang.

Berdasarkan hasil observasi dan wawancara terhadap 20 orang pengguna produk oli pelumas Evalube yang berada di Kota Langsa, diketahui permasalahan yang berkaitan dengan brand image (citra merek) pada produk oli pelumas Evalube. 15 orang konsumen menganggap bahwa merek oli Evalube kurang begitu terkenal sehingga tidak menjadi pertimbangan konsumen dalam memilih produk oli untuk meningkatkan performa kendaraan mereka. Kemudian 5 orang konsumen lainnya mengatakan bahwa kualitas produk Evalube kurang baik karena berdasarkan pengalaman menggunakan oli Evalube konsumen tersebut merasa produk oli pelumas Evalube lebih cepat berubah warna menjadi hitam yang mengakibatkan oli harus lebih sering diganti agar tidak mengganggu performa kendaraannya. Menurut Top Brand Award kategori minyak pelumas motor tahun 2016, produk oli Evalube tidak termasuk 10 besar urutan merek produk oli yang beredar di Indonesia, permasalahan ini memperlihatkan bahwa produk nasional masih kurang mendapat tempat di negaranya sendiri (topbrand-award.com). Hal inilah yang mengakibatkan konsumen tidak memilih oli Evalube untuk kendaraannya karena mereka beranggapan bahwa citra merek oli pelumas
Evalube kurang baik dan memutuskan menggunakan produk oli merek lain sehingga tidak menjadi pelanggan yang loyal terhadap produk oli pelumas Evalube. Penelitian ini dilakukan dengan tujuan untuk mengetahui pengaruh brand image (citra merek) terhadap loyalitas konsumen produk oli pelumas Evalube di Kota Langsa.

\section{Brand (Merek)}

Menurut Kotler (2007), bahwa merek adalah nama, istilah, tanda, simbol, atau rancangan, atau kombinasi dari semuanya, yang dimaksudkan untuk mengidentifikasi barang atau jasa penjual atau kelompok penjual dan untuk mendiferensiasikannya dari barang atau jasa pesaing. Rangkuti (2008) menyatakan merek adalah cara membedakan sebuah nama dan atau simbol (logo, trademark, atau kemasan) yang dimaksudkan untuk mengidentifikasikan barang atau jasa dari satu produsen atau satu kelompok produsen dan untuk membedakan barang atau jasa itu dari produsen pesaing.

Surachman (2011) menjelaskan bahwa brand adalah salah satu atribut yang sangat penting dari sebuah produk yang penggunaannya pada saat ini sudah luas karena beberapa alasan. Salah satunya karena brand suatu produk memberikan nilai tambah produk tersebut. Brand tidak hanya dilihat pada kesan-kesan penggunanya, tetapi harus menempati suatu posisi khusus dalam pikiran untuk benar-benar menjadi sebuan brand. Sunyoto (2012) berpendapat bahwa brand adalah sesuatu yang melekat pada pikiran dan tindakan pelanggan, serta penghubung antara pelanggan dan produk atau perusahaan. Kartajaya (2007) menyatakan merek adalah aset yang menciptakan nilai bagi pelanggan dengan meningkatkan kepuasan dan menghargai kualitas.

Merek pada dasarnya digunakan untuk beberapa tujuan (Tjiptono, 2011) yaitu:

1. Sebagai identitas, yang bermanfaat dalam membedakan produk suatu perusahaan dengan produk pesaingnya.

2. Alat promosi, sebagai daya tarik produk.

3. Untuk membina citra, yaitu dengan memberikan keyakian dan jaminan kualitas kepada konsumen. 
4. Untuk mengendalikan pasar.

\section{Manfaat Brand (Merek)}

Kotler dan Keller (2009) menjelaskan bahwa merek memiliki manfaat bagi perusahaan yaitu sebagai berikut:

1. Menyederhanakan penanganan atau penelusuran produk.

2. Membantu mengatur catatan persediaan dan catatan akuntansi.

3. Menawarkan perlindungan hukum kepada perusahaan untuk fitur-fitur atau aspek unit produk. Bagi perusahaan, merek mempresentasikan bagian properti hukum yang sangat berharga, dapat mempengaruhi konsumen, dapat dibeli dan dijual, serta memberikan keamanan pendapatan masa depan.

Menurut Kotler (2007), merek memiliki banyak peranan bagi penjual, distributor, dan konsumen yaitu:

1. Bagi Penjual

a. Nama merek memudahkan penjual untuk mengolah pesanan-pesanan dan menekankan permasalahan. Dan nama merek diketahui terlebih dahulu oleh konsumen saat membeli atau menggunakan suatu produk.

b. Nama merek dan tanda dagang akan secara hukum melindungi penjual dari pemalsuan ciri-ciri produk, karena bila tidak ada, setiap pesaing akan meniru produk yang telah berhasil di pasaran.

c. Merek memberi penjual peluang kesetiaan konsumen pada produk.

d. Merek dapat membantu penjual dalam mengelompokkan pasar ke dalam segmen-segmen.

2. Bagi Distributor

Distributor menginginkan adanya merek sebagai cara untuk memudahkan penanganan produk, mengidentifikasi, dan meminta produksi agar pada standar mutu tertentu dan juga meningkatkan pilihan para pembeli.

3. Bagi Konsumen

Konsumen

dicantumkannya merek untuk mempermudah mengenali perbedaan mutu serta agar dapat berbelanja dengan lebih efisien.

\section{Syarat-Syarat Memilih Brand (Merek)}

Syarat-syarat merek menurut Alma (2007), harus:

1. Mudah diingat

Memilih merek sebaiknya mudah diingat, baik kata-katanya maupun gambarnya.

2. Menimbulkan kesan positif

Dalam memberikan merek harus dapat diusahakan yang dapat menimbulkan kesan positif terhadap barang atau jasa yang dihasilkan, jangan kesan negatif. Sehingga kesan positif yang diberikan dapat diingat dan melekat di dalam benak konsumen.

3. Tepat untuk promosi

Selain kedua syarat diatas, maka untuk merek tersebut sebaiknya dipilih yang bilamana dipakai promosi sangat baik. Merek-merek yang mudah diingat dan dapat menimbulkan kesan positif tentu baik bila dipakai untuk promosi. Akan tetapi untuk promosi tersebut nama yang indah dan menarik serta gambar-gambar yang bagus juga memegang peranan penting.

\section{Brand Image (Citra Merek)}

Menurut Rangkuti (2008), brand image adalah sekumpulan asosiasi merek yang terbentuk dan melekat di benak konsumen. Kotler (2007) menyatakan citra merekadalah persepsi konsumen tentang suatu merek sebagai refleksi dari asosiasi merek yang ada pada pikiran konsumen. Kotler dan Keller (2009) mendefinisikan citra merek yaitu suatu kesan yang ada didalam benak konsumen mengenai suatu merek yang hal ini dibentuk oleh pesan dan pengalaman konsumen mengenai merek, sehingga menimbulkan citra yang ada dalam benak konsumen.

Menurut Tjiptono (2011), brand image merupakan deskripsi tentang asosiasi dan keyakinan konsumen terhadap merek tertentu. Aaker (2008) berpendapat citra merek merupakan kumpulan asosiasi yang diorganisir menjadi suatu berarti. Citra merek berdasarkan memori konsumen tentang suatu produk, sebagai akibat dari apa yang 
dirasakan oleh seseorang terhadap merek tersebut. Perasaan yang menyenangkan atau tidak menyenangkan terhadap suatu merek akan membentuk citra tersebut dan akan tersimpan dalam memori konsumen. Dan konsumen yang memiliki citra positif terhadap suatu merek, akan memungkinkan untuk melakukan pembelian terhadap suatu produk. Apabila citra merek suatu produk sudah buruk, maka akan menjadi kecil persentase konsumen untuk membelinya, karena konsumen akan tergerak hatinya untuk mencari produk lain yang citra mereknya lebih baik ketimbang produk tersebut.

\section{Faktor-Faktor Pembentuk Brand Image (Citra Merek)}

Menurut Ferrinadewi (2009), faktorfaktor pendukung terbentuknya brand image dapat dijelaskan sebagai berikut:

1. Keunggulan asosiasi merek (favorability of brand association). Hal ini dapat membuat konsumen percaya bahwa atribut dan manfaat yang diberikan oleh suatu brand dapat memuaskan kebutuhan dan keinginan konsumen sehingga menciptakan sikap yang positif terhadap brand tersebut.

2. Kekuatan asosiasi merek (strength of brand association). Hal ini bergantung pada bagaimana informasi masuk dalam ingatan konsumen dan bagaimana informasi tersebut dikelola oleh data sensoris di otak sebagai bagian dari brand image. Ketika konsumen secara aktif memikirkan dan menguraikan arti informasi pada suatu produk atau jasa, akan tercipta asosiasi yang semakin kuat pada ingatan konsumen.

3. Keunikan asosiasi merek (uniqueness of brand association). Sebuah brand haruslah unik dan menarik sehingga produk tersebut memiliki ciri khas dan sulit untuk ditiru para pesaing. Keunikan suatu produk akan memberikan kesan yang cukup membekas terhadap ingatan pelanggan akan keunikan brand.

Rangkuti (2008) menjelaskan bahwa faktor-faktor pembentuk citra merek adalah:

1. Kualitas atau mutu berkaitan dengan kualitas produk barang atau jasa yang ditawarkan oleh produsen dengan merek tertentu.

2. Dapat dipercaya atau diandalkan, berkaitan dengan pendapat atau kesepakatan yang dibentuk oleh masyarakat tentang suatu produk yang dikonsumsi.

3. Kegunaan atau manfaat, yang terkait dengan fungsi dari suatu produk barang atau jasa yang bisa dimanfaatkan oleh konsumen.

4. Pelayanan, yang berkaitan dengan tugas produsen dalam melayani.

5. Resiko, berkaitan dengan besar-kecilnya akibat atau untung-rugi yang mungkin dialami oleh konsumen.

6. Harga, yang dalam hal ini berkaitan dengan tinggi-rendahnya atau banyaksedikitnya jumlah uang yang dikeluarkan konsumen untuk mempengaruhi suatu produk, juga dapat mempengaruhi citra jangka panjang.

7. Citra yang dimiliki oleh merek itu sendiri, yaitu berupa pandangan, kesepakatan, dan informasi yang berkaitan dengan suatu merek dari produk tertentu.

\section{Cara Membangun KeunggulanBrand Image (Citra Merek)}

Langkah-langkah membangun citra merek sebagai berikut (Rangkuti, 2008):

1. Memiliki positioning yang tepat

Merek harus dapat menempati atau memposisikan diri secara tepat untuk selalu menjadi nomor satu dan utama dibenak konsumen.

2. Memiliki brand value yang tepat

Produsen harus membuat brand value yang tepat untuk membentuk brand personality yang baik terhadap merek untuk membuat merek semakin bernilai dan kompetitif dibenak konsumen. Brand personality lebih cepat berubah dibandingkan brand positioning karena brand personality mengikuti permintaan atau kehendak konsumen setiap saat.

3. Memilik konsep yang tepat

Untuk mengkomunikasikan brand value dan positioning yang tepat maka dibutuhkan konsep yang tepat sesuai sasaran baik terhadap produk, segmentasi 
pasar, cara memasarkan, target pasar, dan kualitas pelayanan. Hal ini membantu perusahaan untuk membangun brand image yang baik dibenak konsumen.

\section{Komponen Brand Image (Citra Merek)}

Menurur Ferrinadewi (2009), citra merek terdiri dari tiga komponen, yaitu:

1. Product attributes (Atribut produk) yang merupakan hal-hal yang berkaitan dengan merek tersebut sendiri, seperti kemasan, isi produk, harga, rasa, dan lain-lain.

2. Consumer benefits (Keuntungan konsumen) yang merupakan kegunaan produk dari merek tersebut.

3. Brand personality (Kepribadian merek) merupakan asosiasi yang mengenai kepribadian sebuah merek apabila merek tersebut adalah manusia.

\section{Indikator Brand Image(Citra Merek)}

Kotler dan Keller (2009) berpendapat bahwa indikator-indikator brand image antara lain sebagai berikut:

1. Persepsi konsumen terhadap pengenalan produk.

2. Persepsi konsumen terhadap kualitas produk.

3. Persepsi konsumen terhadap ukuran, apakah dapat memenuhi kebutuhan konsumen atau tidak.

4. Persepsi konsumen terhadap desain atau model kemasan. Semakin menarik desain atau model kemasan tentunya akan semakin menarik produk tersebut dan lebih mudah diingat oleh konsumen.

5. Persepsi konsumen terhadap warna produk.

6. Persepsi konsumen terhadap harga.

Faktor-Faktor yang Mempengaruhi Brand Image (Citra Merek)

Menurut Kartajaya (2007), faktor-faktor yang mempengaruhi brand image adalah:

1. Komunikasi dari sumber lain yang belum tentu sama dengan yang dilakukan pemasar, komunikasi bisa datang dari konsumen lain, pengecer dan pesaing.

2. Pengalaman konsumen melalui suatu eksperimen yang dilakukan konsumen dapat mengubah persepsi yang dimiliki sebelumnya. Oleh sebab itu, berbagai persepsi yang timbul itulah yang akan membentuk total image of brand (citra keseluruhan sebuah merek).

3. Pengembangan produk, posisi brand terhadap produk memang cukup unik, disatu sisi merupakan payung bagi suatu produk, artinya dengan dibekali brand tersebut, produk dapat naik nilainya. Disisi lain, performa ikut membentu brand image yang memayungi den tentunya konsumen akan membandingkan antara performa produk yang telah dirasakan dengan janji brand dalam slogan.

\section{Loyalitas Konsumen}

Menurut Kotler dan Keller (2009), loyalitas adalah komitmen yang dipegang secara mendalam untuk membeli atau mendukung kembali produk atau jasa yang disukai dimasa depan meski pengaruh situasi dan usaha pemasaran berpotensi menyebabkan pelanggan beralih. Hurriyati (2010) menyatakan bahwa loyalitas adalah manifestasi dari kebutuhan fundamental manusia untuk memiliki, men-support, mendapatkan rasa aman dan membangun keterikatan serta menciptakan emotional attachmen. Menurut Tjiptono (2011), loyalitas konsumen adalah komitmen pelanggan terhadap suatu merek, toko atau pemasok berdasarkan sifat yang sangat positif dalam pembelian jangka panjang.

\section{Faktor-Faktor yang Mempengaruhi Loyalitas Konsumen}

Menurut Tjiptono (2011), faktor-faktor yang mempengaruhi loyalitas konsumen adalah:

a. Kepuasan Konsumen

Kepuasan konsumen merupakan pengukuran antara harapan dengan kenyataan yang konsumen terima atau rasakan. Jika apa yang diterima oleh konsumen tidak sesuai dengan harapan, maka pelanggan akan merasa tidak puas. Jika pelanggan puas, mereka akan cenderung untuk kembali bertransaksi dan menjadi lebih loyal

b. Kualitas Produk 
Salah satu faktor penting yang dapat membuat konsumen puas adalah kualitas produk yang mereka terima. Kualitas produk ini akan berpengaruh pada kepuasan konsumen. Jika kualitas tinggi, maka loyalitas konsumen akan meningkat. Begitu juga sebaliknya, jika kualitas rendah maka loyalitas konsumen pun akan menurun.

c. Citra Merek (brand image)

Citra hanya dapat diperoleh melalui sesuatu yang memerlukan waktu kadang cukup lama, namun citra dapat hilang pula dalam sekejap. Para pakar pemasaran sepakat bahwa citra merek yang positif akan semakin penting bagi suatu produk dan loyalitas mudah diperoleh.

\section{Indikator Loyalitas Konsumen}

Menurut Griffin (2005), indikatorindikator loyalitas konsumen antara lain sebagai berikut:

1. Kepuasan menggunakan produk.

2. Berkomitmen menggunakan produk.

3. Tidak membeli produk pesaing.

4. Merekomendasikan produk kepada orang lain.

5. Tidak mencoba produk lain.

6. Melakukan pembelian produk secara berulang.

\section{Jenis-Jenis Loyalitas Konsumen}

Menurut Griffin (2005), jenis-jenis loyalitas konsumen adalah:

1. Tanpa Loyalitas

Untuk berbagai alasan tertentu, ada beberapa konsumen yang tidak mengembangkan loyalitas atau kesetiaan kepada suatu produk maupun jasa tertentu. Pada dasarnya, suatu usaha menghindari kelompok no loyality ini untuk dijadikan target pasar, karena mereka tidak akan menjadi konsumen yang setia.

2. Loyalitas yang Lemah

Loyalitas yang lemah merupakan sebuah jenis loyalitas konsumen yang dimana adanya keterikatan yang rendah dengan pembelian ulang yang tinggi. Konsumen yang memiliki sikap ini biasanya membeli berdasarkan kebiasaan. Pembeli dengan loyalitas yang lemah rentan beralih ke produk pesaing yang dapat menunjukkan manfaat yang jelas.

3. Loyalitas Tersembunyi

Jenis loyalitas tersembunyi merupakan sebuah kesetiaan atau keterikatan yang relatif tinggi dan disertai dengan tingkat pembelian ulang yang rendah. Konsumen yang mempunyai sikap loyalitas tersembunyi melakukan pembelian ulang juga didasarkan pada pengaruh faktor situasional daripada sikapnya.

4. Loyalitas Premium

Loyalitas ini merupakan yang terjadi bilamana suatu tingkat keterikatan tinggi yang berjalan selaras dengan aktivitas pembelian kembali. Setiap perusahaan tentunya sangat mengharapkan kesetiaan jenis ini untuk mendapatkan keuntungan dari usahanya.

\section{Hipotesis}

Menurut Sugiyono (2008), hipotesis merupakan jawaban sementara terhadap rumusan masalah penelitian, dimana rumusan masalah penelitian telah dinyatakan dalam bentuk pertanyaan. Adapun rumusan hipotesis dalam penelitian ini adalah: Brand Image (citra merek) berpengaruh signifikan terhadap loyalitas konsumen produk Oli Pelumas Evalube di Kota Langsa.

\section{METODE PENELITIAN Jenis dan Sumber Data}

Jenis data yang akan digunakan dalam penelitian meliputi data kualitatif dan kuantitatif, dengan penjelasan sebagai berikut:

1. Data kualitatif

Data kualitatif adalah data yang tidak berwujud angka atau data yang dinyatakan dalam bentuk kalimat atau uraian (Tika, 2006). Data kualitatif dalam penelitian ini berupa teori-teori dan gambaran umum objek penelitian.

2. Data kuantitatif

Data kuantitatif adalah data-data yang bersifat angka (Tika, 2006). Data kuantitatif dalam penelitian ini adalah skor kuesioner yang telah diisi oleh responden. 
Sumber data yang akan digunakan dalam penelitian meliputi data primer dan sekunder, dengan penjelasan sebagai berikut:

1. Data primer

Data primer merupakan data yang diperoleh langsung dari narasumber (Lungan, 2006). Data primer dalam penelitian ini diperoleh melalui observasi, wawancara, dan pembagian kuesioner kepada responden.

2. Data sekunder

Data sekunder adalah data yang diperoleh dari sumber pertama atau data yang telah dipublikasikan oleh pihak lain (Lungan, 2006). Data sekunder dalam penelitian ini diperoleh melalui jurnal, buku-buku dan skripsi yang berkaitan dengan penelitian ini.

\section{Populasi dan Sampel}

Populasi dalam penelitian ini adalah konsumen yang pernah membeli dan/atau menggunakan oli pelumas Evalube di Kota Langsa. Jumlah populasi dalam penelitian ini tidak diketahui jumlahnya secara pasti. Maka untuk menentukan jumlah sampel yang pupulasinya tidak diketahui digunakan rumus Unknown Population yang dikemukakan oleh Prasetya (2011), yaitu:

$$
\mathrm{n}=\frac{Z^{2}}{4 \mu^{2}}
$$

Keterangan:

$\mathrm{n} \quad=$ ukuran sampel

$\mathrm{Z}$ = tingkat keyakinan sampel yang dibutuhkan dalam penelitian, pada $\alpha=$ 5\% (derajat keyakinan ditentukan 95\%) maka $\mathrm{Z}=1,96$

$\mu \quad=$ margin of error, tingkat kesalahan yang dapat ditolerir (ditentukan 10\%)

Perhitungannya:

$$
\begin{aligned}
& \mathrm{n}=\frac{Z^{2}}{4 \mu^{2}} \\
& \mathrm{n}=\frac{1,96^{2}}{4(0,1)^{2}} \\
& \mathrm{n}=96,04
\end{aligned}
$$

Berdasarkan perhitungan di atas, maka jumlah sampel dalam penelitian ini adalah 96 orang. Teknik sampling yang digunakan dalam penelitian ini adalah non probability sampling. Menurut Sugiyono (2008) non probability sampling adalah teknik yang tidak memberi peluang atau kesempatan yang sama bagi setiap unsur atau anggota populasi untuk dipilih menjadi sampel. Untuk menentukan siapa yang akan dijadikan sampel menggunakan teknik accidental sampling, yaitu teknik penarikan sampel secara kebetulan, artinya siapa saja anggota populasi yang ditemui saat penelitian dan memenuhi kriteria tertentu maka akan dijadikan sebagai sampel (Sugiyono, 2008).

\section{Metode Pengumpulan Data}

Metode pengumpulan data yang digunakan dalam penelitian ini yaitu:

1. Penelitian lapangan, yang terbagi menjadi:

\section{a. Observasi}

Observasi adalah metode atau caracara menganalisis dan mengadakan pencatatan secara sistematis mengenai tingkah laku dengan mengamati individu secara langsung (Basuki, 2010). Observasi dalam penelitian ini dilakukan pada konsumen yang melakukan pembelian oli pelumas Evalube di Kota Langsa.

b. Wawancara

Wawancara adalah pertemuan dua orang untuk bertukar informasi dan ide melalui tanya jawab, sehingga dapat dikonstruksikan makna dalam suatu topik tertentu (Sugiyono, 2008). Wawancara pada penelitian ini dilakukan terhadap konsumen yang melakukan pembelian oli pelumas Evalube di Kota Langsa.

c. Kuesioner

Kuesioner adalah metode pengumpulan data dengan menyebarkan daftar pernyataan kepada responden tentang objek yang sedang diteliti (Basuki, 2010). Kuesioner pada penelitian ini disebarkan kepada responden produk oli pelumas Evalube di Kota Langsa untuk menjawab pernyataan dengan skala pengukuran menggunakan skala Likert. 
2. Penelitian Kepustakaan

Penelitian kepustakaan adalah hasil penulisan pengarang yang di acu dalam badan tulisan yang mencantumkan namanama penulis dan tahun penerbitan di dalam kurung berupa buku-buku dan jurnal ilmiah (Kuncoro, 2009). Penelitian kepustakaan dalam penelitian ini berupa jurnal, buku-buku dan skripsi yang berkaitan dengan penelitian ini.

\section{Metode Analisis Data}

Dalam penelitian ini menggunakan metode analisis kuantitatif dengan teknik analisis regresi linier sederhana. Menurut Sugiyono (2008) analisis regresi linier sederhana adalah hubungan fungsional antara satu variabel independen (X) dengan satu variabel dependen (Y) yang dirumuskan sebagai berikut:

$\mathrm{Y}=\mathrm{a}+\mathrm{bX}+\mathrm{e}$

\section{Dimana:}

$\mathrm{Y} \quad=$ Variabel terikat

$\mathrm{X} \quad=$ Variabel bebas

a $\quad=$ Konstanta

$\mathrm{b} \quad=$ Koefisien regresi

e $\quad=$ Variabel yang tidak diteliti

\section{HASIL ANALISIS}

Tanggapan Responden pada Variabel Brand Image (Citra Merek)

Mengenai Brand Image (citra merek) pada produk oli pelumas evalube di Kota Langsadiperoleh tanggapan responden yang bervariasi atas pernyataan Brand Image (citra merek) seperti:merek "Evalube" dapat dengan mudah diingat, kualitas oli Evalube sangat bagus, ukuran yang tersedia beragam $(0,8 \mathrm{~L}$ dan 1 L) sehingga kebutuhan motor dapat terpenuhi, desain kemasan (bentuk, logo, dll) Evalube menarik, warna yang digunakan pada kemasan Evalube menarik dan harga oli pelumas Evalube terjangkau.

\section{Tanggapan Responden pada Variabel Loyalitas Konsumen}

Mengenai loyalitas konsumen pada produk oli pelumas evalube di Kota Langsa diperoleh tanggapan responden yang bervariasi atas pernyataan loyalitas konsumen yang terdiri dari:pembelian yang berulang merupakan akibat dari kepuasan yang Anda rasakan terhadap produk oli Evalube, Anda berkomitmen untuk tetap setia menggunakan oli pelumas Evalube, Anda tidak membeli oli merek lain selain oli merek Evalube, Anda merekomendasikan oli pelumas Evalube kepada orang lain, mencoba produk oli lain hanya akan membuat Anda membuang-buang uang dan waktu ketika telah menemukan produk yang pas dengan harapan Anda, dan Anda akan merasa lebih puas ketika mencoba produk oli pelumas Evalube lebih dari sekali.

\section{Pengaruh Brand Image (Citra Merek) Terhadap Loyalitas Konsumen Produk Oli Pelumas Evalube di Kota Langsa.}

Pengaruh brand image (citra merek) terhadap loyalitas konsumen dianalisis menggunakan analisis regresi linear sederhana dengan bantuan programSPSS versi 20.0 for windows.

Berdasarkan Tabel 1 maka dapat dibuat persamaan sebagai berikut:

$$
\mathrm{Y}=1,900+0,576 \mathrm{X}
$$

Dari persamaan regresi tersebut dapat dijelaskan bahwa:

1. Nilai konstanta adalah sebesar 1,900 merupakan nilai loyalitas konsumen sebelum dipengaruhi oleh brand image (citra merek).

2. Koefisien regresi brand image (citra merek) sebesar 0,576 yang memiliki pengaruh positi berarti bahwa jika brand image (citra merek) meningkat sebesar satu satuan maka loyalitas konsumen akan meningkat sebesar 0,576 satuan.

\section{Pembuktian Hipotesis}

Pembuktian hipotesis dilakukan dengan menggunakan hasil analisis data dengan uji $\mathrm{t}$ atau uji secara parsial. Uji $\mathrm{t}$ bertujuan untuk mengetahui pengaruh secara signifikan dari variabel bebas terhadap variabel terikat. Hasil uji t dapat diketahui dengan melihat Tabel 1. Nilai t hitung adalah sebesar 7,517 dan nilai $t$ tabel pada probabilitas 0,05 adalah sebesar 1,985. Oleh karena $t_{\text {hitung }}>\mathrm{t}_{\text {tabel }}(7,517>1,985)$ dan nilai $\mathrm{t}$ 
Tabel 1. Hasil Analisis Statistik

\begin{tabular}{|c|c|c|c|}
\hline Variabel & B & $\mathrm{T}$ & Sig. $\mathrm{t}$ \\
\hline Konstanta & 1,900 & 5,929 & 0,000 \\
\hline Brand Image (Citra Merek) & 0,576 & 7,517 & 0,000 \\
\hline R. Square & $=0,375$ & & \\
\hline
\end{tabular}

Sumber: Data Primer diolah, 2017

sig yaitu $0,000<0,05$ dapat dinyatakan bahwa hipotesis diterima, artinya brand image (citra merek) berpengaruh signifikan terhadap loyalitas konsumen produk oli pelumas evalube di kota Langsa.

\section{Koefisien Determinasi $\left(\mathbf{R}^{\mathbf{2}}\right)$}

Berdasarkan Tabel 1 diketahui nilai koefisien determinasi $\left(\mathrm{R}^{2}\right)$ yaitu 0,375 atau 37,5\%. Hal ini menunjukkan variabel brand image (citra merek) mempengaruhi loyalitas konsumen produk oli pelumas Evalube di kota Langsa sebesar $37,5 \%$, dan sisanya $62,5 \%$ dipengaruhi oleh variabel lain yang tidak diteliti dalam penelitian ini.

\section{KESIMPULAN}

Berdasarkan hasil penelitian dan pembahasan, maka kesimpulan yang dapat ditarik pada penelitian ini adalah sebagai berikut:

1. Hasil persamaan regresi diperoleh $\mathrm{Y}=$ $1,900+0,576 \mathrm{X}$.

2. Brand image (citra merek) berpengaruh signifikan terhadap loyalitas konsumen produk oli pelumas evalube di kota Langsa diterima.

3. Nilai koefisien determinasi $\left(\mathrm{R}^{2}\right)$ diperoleh sebesar 0,375 atau $37,5 \%$ yang artinya variabel brand image (citra merek) memberikan pengaruh terhadap loyalitas konsumen sebesar $37,5 \%$ dan sisanya $62,5 \%$ dipengaruhi oleh variabel lain yang tidak diteliti dalam penelitian ini.

\section{Saran} yaitu:

Adapun saran dalam penelitian ini

1. Perusahaan harus meningkatkan kualitas produk sehingga oli pelumas Evalube dapat menjadi pilihan konsumen dalam penggunaan oli kendaraannya dan dapat menciptakan loyalitas konsumen.

2. Perusahaan harus meningkatkan citra merek dengan cara melakukan promosi yang gencar melalui penayangan iklan di televisi, radio, surat kabar, majalah, bilboard dan sarana iklan lainnya.

3. Perusahaan harus membuat Tag Line produk yang unik, menarik dan mudah diingat.

4. Endorser yang digunakan harus memiliki reputasi yang baik dan terkenal.

\section{DAFTAR PUSTAKA}

Aaker, A. David. 2008. Manajemen Ekuitas Merek. Alih bahasa oleh Aris Ananda. Jakarta: Mitra Utama.

Alma, Buchari. 2007. Manajemen Pemasaran dan Pemasaran Jasa. Bandung: Alfabeta

Basuki, Sulistyo. 2010. Metode Penelitian. Jakarta: Penaku.

Ferrinadewi, Erna. 2009. Merek \& Psikologi Konsumen: Implikasi pada Strategi Pemasaran. Yogyakarta: Graha Ilmu.

Griffin, Jill. 2005. Customer Loyalty: Menumbuhkan dan Mempertahankan Kesetiaan Pelanggan. Jakarta: Erlangga.

Hurriyati, Ratih. 2010. Bauran Pemasaran dan Loyalitas Konsumen. Jakarta: Alfabeta.

Kartajaya, Hermawan. 2007. Marketing In Venus. Jakarta: Gramedia.

Kotler, Philip. 2007. Manajemen Pemasaran. Edisi 12, Jilid 1. Jakarta:Indeks-Prentice Hall.

Kotler, Philip dan Kevin Lane Keller. 2009. Manajemen Pemasaran Jilid 1, Edisi 
ke 13. Terjemahan Bob Sabran. Jakarta: Erlangga.

Kresnamurti, Agung dan Ariani Putri. 2012. Pengaruh Kualitas Produk dan Citra Merek Terhadap Loyalitas Konsumen pada Produk Oli Federal di Wilayah Jakarta Timur. Jurnal Econo Sains. Vol X. Nomor 1. Hal: 1-14.

Kuncoro, Mudjarad. 2009. Metode Riset Untuk Bisnis dan Ekonomi. Jakarta: Erlangga

Lungan, Richard. 2006. Aplikasi Statistika dan Hitung Peluang. Yogyakarta: Graha Ilmu.

Pradipta, Dyah Ayu Anisha. 2012. Pengaruh Citra Merek (Brand Image) terhadap Loyalitas Konsumen Produk Oli Pelumas PT. Pertamina (Persero) Enduro 4T di Makassar. Skripsi. Fakultas Ekonomi dan Bisnis. Universitas Hasanuddin. Makasar.
Prasetya. 2011. Metode Penelitian

Kuantitatif. Jakarta: Rajawali Pers.

Rangkuti, Freddy. 2008. The Power Of

Brands. Jakarta: Erlangga.

Sugiyono. 2008. Metode Penelitian Kuantitatif Kualitatif dan R\&D. Bandung: Alfabeta.

Sunyoto, Danang. 2012. Dasar-dasar Manajemen Pemasaran. Yogyakarta: CAPS.

Surachman. 2011. Dasar-dasar Manajemen Merek. Bayumedia: Malang.

Tika, Moh. Pabundu. 2006. Metodologi Riset Bisnis. Jakarta: PT. Bumi Aksara.

Tjiptono, Fandy. 2011. Strategi Bisnis

Pemasaran. Yogyakarta: Andi 